Supporting information

\title{
Ultrasensitive on-site detection of biological active ricin in complex \\ food matrices based on immunomagnetic enrichment and \\ fluorescence switch-on nanoprobe
}

Jiefang Sun ${ }^{\mathrm{a}}$, Xueyong Zhang ${ }^{\mathrm{c}}$, Ting Lid ${ }^{\mathrm{d}}$, Jijia Xie ${ }^{\mathrm{e}}$, Bing Shao ${ }^{\mathrm{a}, b^{*}}$, Dingshuai Xue ${ }^{\mathrm{f}}, \mathrm{Xu}$ Tang ${ }^{\mathrm{f}}$, Hui Li ${ }^{\mathrm{a}}$, Yanhong Liu ${ }^{\mathrm{f}}$

aBeijing Key Laboratory of Diagnostic and Traceability Technologies for Food poisoning, Beijing Center for Disease Prevention and Control, Beijing 100013, China

bBeijing Advanced Innovation Center for Food Nutrition and Human Health, China

Agricultural University, Beijing 100193, China

'School of Police Law Enforcement Abilities Training, People's Public Security University of

China, Beijing 100038, China

dSchool of Public Health, Capital Medical University, Beijing 100069, China

eDepartment of Chemical Engineering, University College London, Torrington Place, London $\mathrm{WC}_{1} \mathrm{E}_{7} \mathrm{JE}$, UK

fState Key Laboratory of Lithospheric Evolution, Institute of Geology and Geophysics, Chinese Academy of Sciences, Beijing 100029, China

*Corresponding authors: Tel.: +861064407191; E-mail addresses: shaobingch@sina.com 


\section{Table of content}

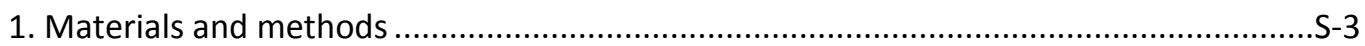

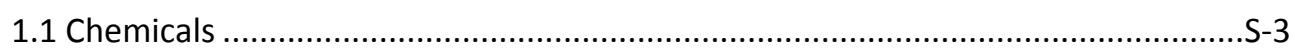

1.2 Preparation of food samples ........................................................................

1.3 Synthesis of 3-methacryloylaminopropyl-2-carboxyethyl-dimethylammonium

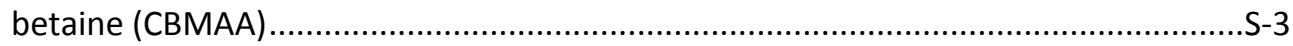

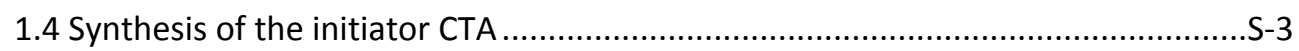

1.5 RAFT polymerization and high-capacity antibody immobilization on MBs .............S-4

1.6 Modification of SSODN on both QDs and AuNPs...............................................

1.7 Determination of the released adenine using the LC-MS method........................ -5

1.8 Determination of the recovered ricin using the LC-MS/MS based method ............S-6

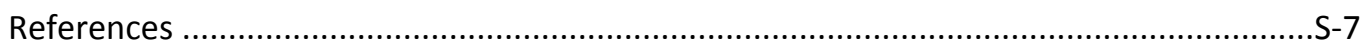

Table S1 MRM parameters of this method ...................................................... -8

Table S2. Comparison of the recovery capacities of different affinity magnetic adsorbents in complex matrices. The concentration of ricin was determined by the

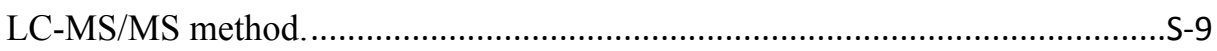

Table S3. dsODN molecule beacons used to react with active ricin ..................S-10

Table S4 Comparison of different assays available for determining active ricin .S-11

Figure S1. XRD results of the different magnetic materials

Figure S2. The fluorescence of the molecule beacons S1 (A), S2 (B) and S3 (C) before and after adding active ricin $\left(20 \mathrm{ng} \mathrm{mL}^{-1}\right)$.

Figure S3. The background signal and the signal response of the AuNP/QDs nanoprobe under different ratios.

Figure S4. Comparison of the response of AuNP/QDs to active ricin dispersed in ammonium acetate buffer ( $5 \mathrm{mmol} \mathrm{L}^{-1}, \mathrm{pH} 4.0$, blank line), the elution condition (incube 30 ) as well as in diluted elution buffer (blue line) which contained ammonium acetate buffer ( $\left.4.5 \mathrm{mmol} \mathrm{L}^{-1}, \mathrm{pH} 4.0\right), 4.9 \%$ ethanol and TFA (0.1\%). The fluorescence intensity of the AuNP/QDs at $575 \mathrm{~nm}\left(\mathrm{I}_{575}\right)$ was plotted against different concentration of active ricin.

Figure S5. Comparison of the response of AuNP/QDs to active ricin before (blank line) and after (red line) storing 4 months in the PBS under $4^{\circ} \mathrm{C}$. The fluorescence intensity of the AuNP/QDs at $575 \mathrm{~nm}\left(\mathrm{I}_{575}\right)$ was plotted against different concentration of active ricin. S-15 


\section{Materials and methods}

\subsection{Chemicals}

2-(Dimethylamino)ethyl methacrylate (DMAEMA), $\beta$-propiolactone, anhydrous THF, 1-propanethiol, anhydrous acetone, $\mathrm{CS}_{2}$, (4-(chloromethyl)phenyl)-trimethoxysilane dichloromethane, 2,2'-Azobisisobutyronitrile (AIBN) were purchased from J\&K Chemical.

\subsection{Preparation of food samples}

The crude food and biological samples for this research were prepared from diluted human serum, orange juice, coffee, fresh milk, ham and sandwich. The solid samples were weighted and diluted with PBS buffer (1.0 mL per gram) homogenized for $5 \mathrm{~min}$ following by centrifuging for $2 \mathrm{~min}$ at $1,200 \mathrm{rpm}$ to remove large residual. The supernatant was frozen until used. The human serum was diluted 5 times with phosphate-buffered saline (PBS) buffer before analysis.

\subsection{Synthesis of 3-methacryloylaminopropyl-2-carboxyethyl-dimethylammonium betaine (CBMAA)}

3-methacryloylaminoethyl-2-carboxyethyl-dimethylammonium betaine (carboxybetaine methacrylamide) (CBMAA) was synthesized according to a previously published procedure for a similar monomer [1]. In detail, DMAEMA (19.4 $\mathrm{g}, 114 \mathrm{mmol}$ ) was dissolved in $100 \mathrm{~mL}$ of anhydrous THF in a round bottom flask under vigorous stirring and cooled to $0^{\circ} \mathrm{C}$. Subsequently, $\beta$-propiolactone $(11.5 \mathrm{~g}, 160 \mathrm{mmol})$ was dissolved in $30 \mathrm{~mL}$ of anhydrous THF and added dropwise under argon for a period of about $1 \mathrm{~h}$. The reaction was allowed to proceed for $24 \mathrm{~h}$ at $4{ }^{\circ} \mathrm{C}$ in a refrigerator. The white precipitate was filtered off, washed with anhydrous THF and ether, and dried under high vacuum. The product was confirmed by ${ }^{1} \mathrm{H}$ NMR (Bruker $300 \mathrm{MHz}$ in $\mathrm{D}_{2} \mathrm{O}$ ).

\subsection{Synthesis of the initiator CTA}

The silane functionalized reversible addition - fragmentation chain transfer (RAFT) 
initiator, propyl-4-(trimethoxysilyl) benzyl carbonotrithioate (CTA), was synthesized according to the literature [2]. In detail, 1-propanethiol $(6.6 \mathrm{mmol})$ was charged into a stirred suspension of $\mathrm{K}_{3} \mathrm{PO}_{4}(1.02 \mathrm{~g}, 6.6 \mathrm{mmol})$ in anhydrous acetone $(15 \mathrm{~mL})$, followed by stirring for about half an hour. $\mathrm{CS}_{2}(1.1 \mathrm{~mL}, 18 \mathrm{mmol})$ was added and the solution turned to bright yellow. After stirring for another $10 \mathrm{~min}$, (4-(chloromethyl)phenyl)trimethoxysilane $(1.43 \mathrm{~mL}, 6.6 \mathrm{mmol})$ was added and the mixture was then stirred at ambient temperature in nitrogen atmosphere for $13 \mathrm{~h}$. The mixture was concentrated, diluted with dichloromethane and filtered off. After removing the solvent from the filtrate under reduced pressure the resulting yellow residue was purified by column chromatography on silica gel using a petroleum ether/ethyl acetate gradient to yield a bright yellow oil. The product was confirmed by ${ }^{1} \mathrm{H}$ NMR (Bruker $300 \mathrm{MHz}$ in D2O).

\subsection{RAFT polymerization and high-capacity antibody immobilization on MBs}

For preparing the poly(CBMAA-ran-HEMA) polymer (P(C-H)), AIBN (20 mg), HEMA (1.0 mL) and CBMAA $(0.3 \mathrm{~g})$ were dissolved in $10 \mathrm{~mL}$ of degassed DMF solution. After $\mathrm{N}_{2}$ bubbling for $30 \mathrm{~min}$, the system was sealed and heating under $80{ }^{\circ} \mathrm{C}$. After reaction for $5 \mathrm{~h}$, the product was diluted and washed by DI water for 3 times.

To modify $\mathrm{Fe}_{3} \mathrm{O}_{4} @ \mathrm{SiO}_{2}(\mathrm{MBs})$ with RAFT initiator, $50 \mathrm{mg}$ of CTA was added into 100 $\mathrm{mL}$ suspension of MBs in absolute ethanol $\left(1.0 \mathrm{mg} \mathrm{mL}^{-1}\right)$, followed by refluxing under nitrogen for $5 \mathrm{~h}$. The obtained CTA-MBs was collected and washed with ethanol for 3 times. Finally, the CTA-MBs was suspended in ethanol for further use.

For grafting the $\mathrm{P}(\mathrm{C}-\mathrm{H})$ ) brushes from the MBs, CTA-MBs (0.1g), AIBN (20mg), HEMA $(1.0 \mathrm{~mL})$ and CBMAA $(0.3 \mathrm{~g})$ were dissolved in $10 \mathrm{~mL}$ of degassed water/methanol (1:1) solution. After $\mathrm{N}_{2}$ bubbling for $30 \mathrm{~min}$, the system was sealed and heating under $80{ }^{\circ} \mathrm{C}$. After reaction for $5 \mathrm{~h}$, the product was diluted and washed by DMF for 3 times.

Ricin mono-antibody $\left(\mathrm{mAb}_{\text {ricin }}\right)$ was covalent linked on the $\mathrm{MB} @ \mathrm{P}(\mathrm{H}-\mathrm{C})$ by a typical EDC coupling procedure. The MB@P(H-C) $(0.1 \mathrm{~g}$ in $10 \mathrm{~mL})$ was firstly activated by sulfo-NHS (10 mg mL-1) and EDC (20 mg mL-1) in $1.0 \mathrm{~mL}$ of $10 \mathrm{mM} \mathrm{MES} \mathrm{buffer.}$ 
After 30min, the supernatant was removed, followed by adding $10 \mathrm{mg} \mathrm{mAb}$ ricin dispersed in $10 \mathrm{mM}$ PBS solution. The reaction processed for $5 \mathrm{~h}$ under room temperature, and then quenched with $0.5 \%$ glycine overnight at $4 \mathrm{C}$. BCA protein quantitative assay was performed to verify the linkage between mAb $b_{\text {ricin }}$ and $\mathrm{MB} @ \mathrm{P}(\mathrm{H}-$ C).

\subsection{Modification of ssODN on both QDs and AuNPs}

AuNPs with diameter of ca.60 nm were prepared via the seed grow method [3]. For stabilizing AuNPs, BSPP (15 mg) was added to the AuNP sol (100 mL) under stirring, further reacted at least 10 hours. The BSPP-AuNP sol was centrifuged, followed by removing the supernatant, finally re-dispersing in $10 \mathrm{~mL}$ ultrapure water. The P1 modified AuNPs (the P1-AuNPs) were obtained via the strong binding between Au and thiol. The P1 $\left(0.1 \mathrm{mmol} \mathrm{L}^{-1}, 50 \mu \mathrm{L}\right)$ was treated with a 5-fold molar excess of TCEP at $50{ }^{\circ} \mathrm{C}$ for $1 \mathrm{~h}$ to reduce disulfide bonds, and then added to $10 \mathrm{~mL}$ of the BSPP-AuNP sol. In the incubating process, $\mathrm{NaCl}\left(0.1 \mathrm{~mL}, 0.1 \mathrm{~mol} \mathrm{~L}^{-1}\right)$ was added every 2 hours. After $10 \mathrm{~h}$, the P1-AuNPs were centrifuged at $8000 \mathrm{rpm}$ for $10 \mathrm{~min}$ and the supernatant was carefully removed. The P2 modified QDs (P2-QDs) were prepared using EDC/sulfo-NHS cross-linking method. The commercial QDs was purified by ultracentrification firstly, and then diluted to $1.0 \mu \mathrm{M}$ using ultrapure water. The QDs was activated by sulfo-NHS $\left(0.1 \mathrm{mg} \mathrm{mL}^{-1}\right)$ and EDC $\left(0.1 \mathrm{mg} \mathrm{mL}^{-1}\right)$ in $1.0 \mathrm{~mL}$ of $1.0 \mathrm{mM}$ MES buffer. The P2 $\left(0.1 \mathrm{mmol} \mathrm{L}^{-1}, 100 \mu \mathrm{L}\right)$ was added to the active QD solution after reacting $30 \mathrm{~min}$, and the $\mathrm{pH}$ was adjusted to 8.5 by adding $0.1 \mathrm{M} \mathrm{NaHCO}_{3}(0.2 \mathrm{~mL})$. The reaction processed for extra $10 \mathrm{~h}$ under room temperature, and then quenched with $0.5 \%$ glycine overnight at $4 \mathrm{C}$. The P2-QDs were purified via Separose $50 \mathrm{G}$.

\subsection{Determination of the released adenine using the LC-MS method}

The released adenine was determined by LC-ESI-TOF/MS as below. Chromatographic separations were performed on Xtarre C18 HPLC column $(2.1 \times 150 \mathrm{~mm}, 3.5 \mu \mathrm{m}, 80$ $\AA$ ). Mobile phase consisted of $10 \%$ methanol and $90 \% 20 \mathrm{mmol} \mathrm{L}^{-1}$ ammonium formate containing $0.1 \%$ formic acid, $\mathrm{pH} 4.0$. The flow rate was $0.2 \mathrm{~mL} \mathrm{~min}^{-1}$, and the 
injection volume was $5 \mu \mathrm{L}$. The HPLC eluent was directly introduced to the LCT by electrospray ionization (ESI) operating in positive ion mode. The ESI parameters were as follows: capillary voltage $3 \mathrm{kV}$, sample cone voltage $20 \mathrm{~V}$, extraction cone voltage $5 \mathrm{~V}$, desolvation temperature $250{ }^{\circ} \mathrm{C}$, source temperature $130{ }^{\circ} \mathrm{C}$. The mass spectrometer was operated in selected ion monitoring mode using an m/z values of 136 $[\mathrm{M}+\mathrm{H}]^{+}$for adenine and $226[\mathrm{M}+\mathrm{H}]^{+}$for acyclovir (internal standard).

\subsection{Determination of the recovered ricin using the LC-MS/MS based method}

The recovered ricin by using the $\mathrm{MB} @ \mathrm{P}(\mathrm{C}-\mathrm{H})-\mathrm{mAb}$ ricin was quantification by the liquid chromatography electrospray ionization tandem mass spectrometry. The enriched ricin was firstly eluted and dried by cryogenic centrifuge concentration. Subsequently, it was redissolved in $100 \mu \mathrm{L}$ of $50 \mathrm{mmol} \mathrm{L}^{-1} \mathrm{NH}_{4} \mathrm{HCO}_{3}$, followed by being reduced using 1.0 M DTT $(1.0 \mu \mathrm{L})$ for $10 \mathrm{~min}$ at $95{ }^{\circ} \mathrm{C}$. The reduced thiol groups were alkylated with 1.0 M IAA $(2.0 \mu \mathrm{L})$ for $1 \mathrm{~h}$ under dark environment. Finally, $1 \mu \mathrm{L}$ of $1 \mathrm{mg} \mathrm{mL} \mathrm{m}^{-1}$ trypsin was added to the denatured protein solution at an enzyme-toprotein of 1:50 (w/w). After enzymolysis at $37{ }^{\circ} \mathrm{C}$ for $12 \mathrm{~h}, 1 \mu \mathrm{L}$ of TFA was added to quench the reaction. The resulted samples were then centrifuged at $10,000 \times \mathrm{g}$ for analyze.

The best sensitive peptide named T7A (49VGLPINQR56) was used as the quantification peptide. All quantification data were acquired on a mass spectrometer LCMS-8060 (Shimazu, Japan) with an elecrospray ion (ESI+) mode. The conditions of MS/MS were set as follows: interface Voltage, $3 \mathrm{kV}$; nebulizing gas $\left(\mathrm{N}_{2}\right), 3.0 \mathrm{~L} \mathrm{~min}^{-1}$; heating gas (air), $10 \mathrm{~L} \mathrm{~min}^{-1}$; drying Gas $\left(\mathrm{N}_{2}\right), 10 \mathrm{~L} \mathrm{~min}^{-1}$; collison gas, Ar; interface temperature, $300^{\circ} \mathrm{C}$; DL temperature, $250^{\circ} \mathrm{C}$; heat block temperature, $400{ }^{\circ} \mathrm{C}$; analysis type, MRM; MRM parameters are shown in Table S1.

The signature peptides was separated by a LC-30A ultra-high-performance liquid chromatography system (Shimazu, Japan). Digest samples were loaded onto a Waters ACQUITY UPLC ${ }^{\circledR}$ Peptide $\mathrm{CSH}^{\mathrm{TM}} \mathrm{C} 18(130 \AA, 1.7 \mu \mathrm{m}, 2.1 \mathrm{~mm} \times 100 \mathrm{~mm})$ with a column temperature at $55^{\circ} \mathrm{C}$. The injection volume was $10 \mu \mathrm{L}$. The mobile phase consist 
of (Solvent A) water with $0.1 \%$ FA and (Solvent B) ACN with $0.1 \%$ FA. A binary solvent was run at $0.3 \mathrm{~mL} \mathrm{~min}^{-1}$, the binary solvent gradient was started with $2 \% \mathrm{~B}$ for $1 \mathrm{~min}$, linearly from $2 \%$ to $30 \% \mathrm{~B}$ in $5.5 \mathrm{~min}$, linearly from $30 \%$ to $80 \% \mathrm{~B}$ in 0.5 min, held at $80 \% \mathrm{~B}$ for $0.5 \mathrm{~min}$, back to $2 \% \mathrm{~B}$ in $0.1 \mathrm{~min}$ then stay at $2 \%$ for $1.4 \mathrm{~min}$.

\section{References}

[1] Banerjee, I., Pangule, R.C., Kane, R.S., Antifouling coatings: recent developments in the design of surfaces that prevent fouling by proteins, bacteria, and marine organisms. Adv. Mater. 2011, 23, 690-718.

[2] Qu, Z., Hu, F., Chen, K., Duan, Z., Gu, H., Xu, H., A facile route to the synthesis of spherical poly (acrylic acid) brushes via RAFT polymerization for high-capacity protein immobilization. J. Colloid and Interface Sci. 2013, 398, 82-87.

[3] Bastús, N.G., Comenge, J., Puntes, V., Kinetically controlled seeded growth synthesis of citrate-stabilized gold nanoparticles of up to $200 \mathrm{~nm}$ : size focusing versus Ostwald ripening. Langmuir 2011, 27, 11098-11105.

[4] Sun, J., Wang, C., Shao, B., Wang, Z., Xue, D., Liu, Y., Qi, K., Yang, Y., Niu, Y., Fast on-site visual detection of active ricin using a combination of highly efficient dual-recognition affinity magnetic enrichment and a specific gold nanoparticle probe. Anal. Chem. 2017, 89, 12209-12216.

[5] Sturm, M.B., Schramm, V.L., Detecting ricin: sensitive luminescent assay for ricin A-chain ribosome depurination kinetics. Anal. Chem. 2009, 81, 2847-2853.

[6] Bevilacqua, V.H., Nilles, J.M., Rice, J.S., Connell, T.R., Schenning, A.M., Reilly, L.M., Durst, H.D., Ricin activity assay by direct analysis in real time mass spectrometry detection of adenine release. Anal. Chem. 2010, 82, 798-800.

[7] Kalb, S.R., Barr, J.R., Mass spectrometric detection of ricin and its activity in food and clinical samples. Anal. Chem. 2009, 81, 2037-2042.

[8] Tang, J., Sun, J., Liu, R., Zhang, Z., Liu, J., Xie, J., New surface-enhanced Raman sensing chip designed for on-site detection of active ricin in complex matrices based on specific depurination. ACS Applied Materials \& Interfaces 2016, 8, 2449-2455.

[9] Wang, D., Baudys, J., Barr, J.R., Kalb, S.R., Improved sensitivity for the qualitative and quantitative analysis of active ricin by MALDI-TOF mass spectrometry. Anal. Chem. 2016, 88, 6867-6872. 
Table S1 MRM parameters of this method

\begin{tabular}{lccccc} 
Peptides & Precursor ion $(m / z)$ & Product ion $(m / z)$ & Q1 $(V)$ & CE(V) & Q3(V) \\
\hline & {$[627.4]^{+}$} & -14 & -17 & -22 \\
VGLPINQR $[448.8]^{2+}$ & {$[314.2]^{2+}$} & -12 & -19 & -15 \\
\hline
\end{tabular}


Table S2. Comparison of the recovery capacities of different affinity magnetic adsorbents in complex matrices. The concentration of ricin was determined by the LCMS/MS method.

\begin{tabular}{|c|c|c|c|c|}
\hline \multirow[b]{2}{*}{ Sample } & \multirow[b]{2}{*}{$\begin{array}{l}\text { Spiked } \\
\left(\mathrm{ng} \mathrm{mL}^{-1}\right)\end{array}$} & \multicolumn{2}{|c|}{$\begin{array}{l}\text { Ricin enriched by the } \\
\text { MB@P(C-H)-mAb } b_{\text {ricin }}\left(\mathrm{ng} \mathrm{mL}^{-1}\right)\end{array}$} & \multirow{2}{*}{$\begin{array}{l}\text { Ricin enriched by the } \\
\mathrm{MB} @ \mathrm{P}(\mathrm{ConA} / \mathrm{Gal}) \\
\left(\mathrm{ng} \mathrm{mL}^{-1}\right)\end{array}$} \\
\hline & & $\begin{array}{l}\text { Eluting by the } \\
\text { TFA/DI } \\
\text { water/ethanol } \\
1: 50: 49(\mathrm{v} / \mathrm{v} / \mathrm{v})\end{array}$ & $\begin{array}{lcr}\text { Eluting } & \text { by } & \text { the } \\
\text { TFA/DI } & \text { water } & 1: 99 \\
(\mathrm{v} / \mathrm{v}) & & \end{array}$ & \\
\hline \multirow{2}{*}{$\begin{array}{l}\text { Diluted } \\
\text { Human serum }\end{array}$} & 20.0 & 14.6 & 12.5 & 10.2 \\
\hline & 50.0 & 43.1 & 39.2 & 28.3 \\
\hline \multirow{2}{*}{ Orange juice } & 20.0 & 16.8 & 13.3 & 12.2 \\
\hline & 50.0 & 44.5 & 40.3 & 32.5 \\
\hline \multirow{2}{*}{ ham } & 20.0 & 13.2 & 10.9 & 8.2 \\
\hline & 50.0 & 39.3 & 35.9 & 19.8 \\
\hline \multirow{2}{*}{ Sandwich } & 20.0 & 13.7 & 11.7 & 7.8 \\
\hline & 50.0 & 38.5 & 34.3 & 21.6 \\
\hline \multirow{2}{*}{ Milk } & 20.0 & 15.7 & 12.4 & 8.6 \\
\hline & 50.0 & 42.3 & 38.1 & 24.3 \\
\hline \multirow{2}{*}{ coffee } & 20.0 & 15.4 & 12.5 & 11.2 \\
\hline & 50.0 & 45.2 & 41.8 & 37.6 \\
\hline
\end{tabular}


Table S3. dsODN molecule beacons used to react with active ricin

\begin{tabular}{|c|c|}
\hline Name & Sequence \\
\hline $\mathrm{S} 1$ & 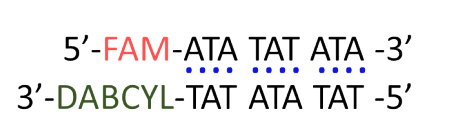 \\
\hline $\mathrm{S} 2$ & $\begin{array}{r}\text { 5'-FAM-ATA TAT ATA TAT-3' } \\
3^{\prime} \text {-DABCYL-T̈AT Ä̈Ä TÄ Ä̈̈̈̈-5' }\end{array}$ \\
\hline S3 & 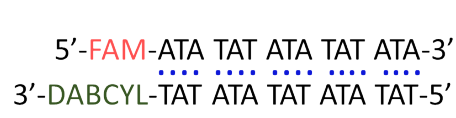 \\
\hline
\end{tabular}


Table S4 Comparison of different assays available for determining active ricin

\begin{tabular}{|c|c|c|c|c|c|}
\hline Method & $\begin{array}{l}\text { Require } \\
\text { time }\end{array}$ & Instruments & LOD & Sample & Ref. \\
\hline $\begin{array}{l}\text { Immuno-magnetic enrichment } \\
\text { and fluorescence Assay }\end{array}$ & Nearly $4 \mathrm{~h}$ & $\begin{array}{l}\text { naked eyes or } \\
\text { spectrophotometer }\end{array}$ & $7.46 \mathrm{ng} \mathrm{mL}^{-1}$ & $\begin{array}{l}\text { diluted human serum, } \\
\text { orange juice, coffee } \\
\text { milk, ham, sandwich }\end{array}$ & $\begin{array}{l}\text { Present } \\
\text { Method }\end{array}$ \\
\hline $\begin{array}{l}\text { Affinity magnetic enrichment } \\
\text { and colorimetric Assay }\end{array}$ & Nearly $4 \mathrm{~h}$ & $\begin{array}{l}\text { naked eyes or UV-vis } \\
\text { spectrophotometer }\end{array}$ & $12.5 \mathrm{ng} \mathrm{mL}^{-1}$ & $\begin{array}{l}\text { apple juice, lettuce } \\
\text { juice, diluted human } \\
\text { serum, drinking water }\end{array}$ & Ref. 4 \\
\hline Luminescent Assay & Nearly 2 h & spectrophotometer & $0.8 \mathrm{ng} \mathrm{mL}^{-1}$ & Buffer solution & Ref. 5 \\
\hline Real-time MS Detection & Nearly $6 \mathrm{~h}$ & mass spectrometer & $5.7 \mu \mathrm{g} \mathrm{mL}^{-1}$ & Buffer solution & Ref. 6 \\
\hline $\begin{array}{l}\text { Immunocapture and mass } \\
\text { spectra detection }\end{array}$ & Nearly $4 \mathrm{~h}$ & mass spectrometer & $0.32 \mathrm{ng} \mathrm{mL}^{-1}$ & $\begin{array}{l}\text { milk, apple juice, } \\
\text { serum, saliva }\end{array}$ & Ref. 7 \\
\hline SERS assay & Nearly $3 \mathrm{~h}$ & Raman spectrometer & $8.9 \mathrm{ng} \mathrm{mL}^{-1}$ & $\begin{array}{l}\text { apple juice, diluted } \\
\text { human serum, drinking } \\
\text { water }\end{array}$ & Ref. 8 \\
\hline $\begin{array}{l}\text { Immunomagnetic enrichment } \\
\text { and MALDI-TOF detection }\end{array}$ & Nearly 6 h & $\begin{array}{l}\text { MALDI-TOF } \\
\text { mass spectra }\end{array}$ & $0.2 \mathrm{ng} \mathrm{mL}^{-1}$ & buffer and milk & Ref. 9 \\
\hline
\end{tabular}




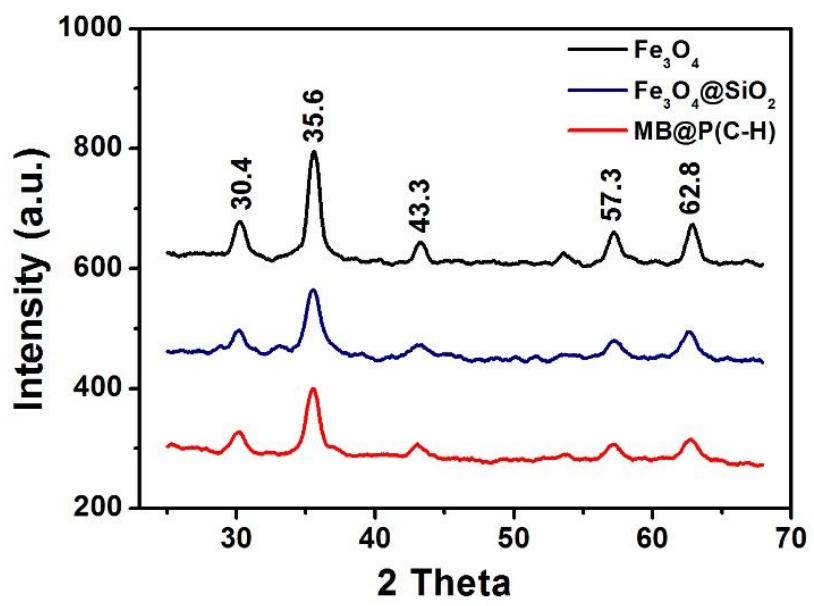

Figure S1. XRD results of the different magnetic materials. 

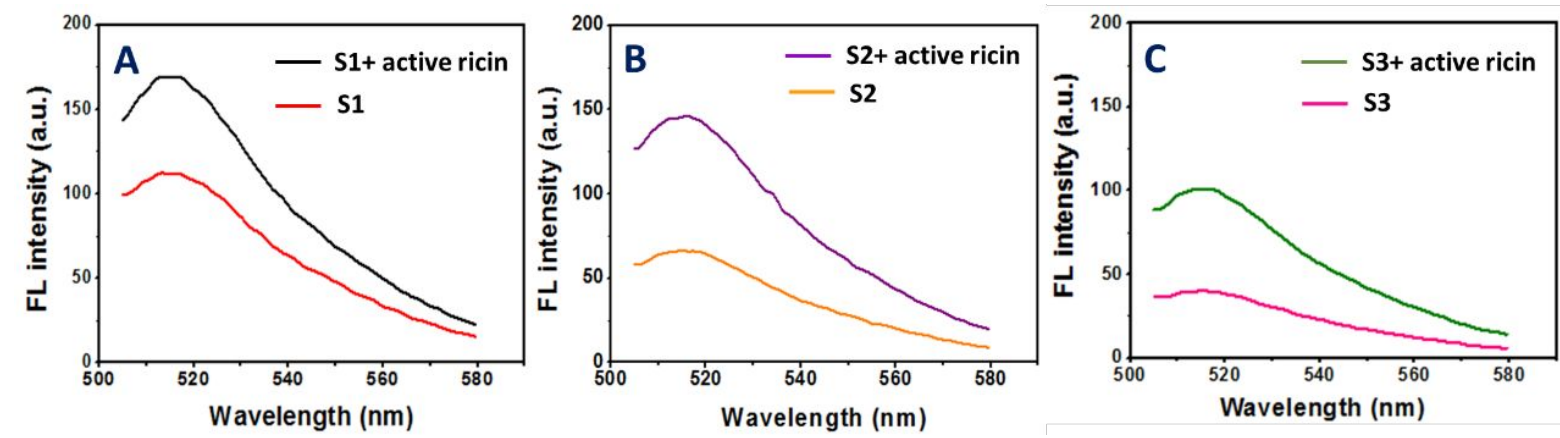

Figure S2. The fluorescence of the molecule beacons S1 (A), S2 (B) and S3 (C) before and after adding active ricin (20 $\left.\mathrm{ng} \mathrm{mL}^{-1}\right)$.

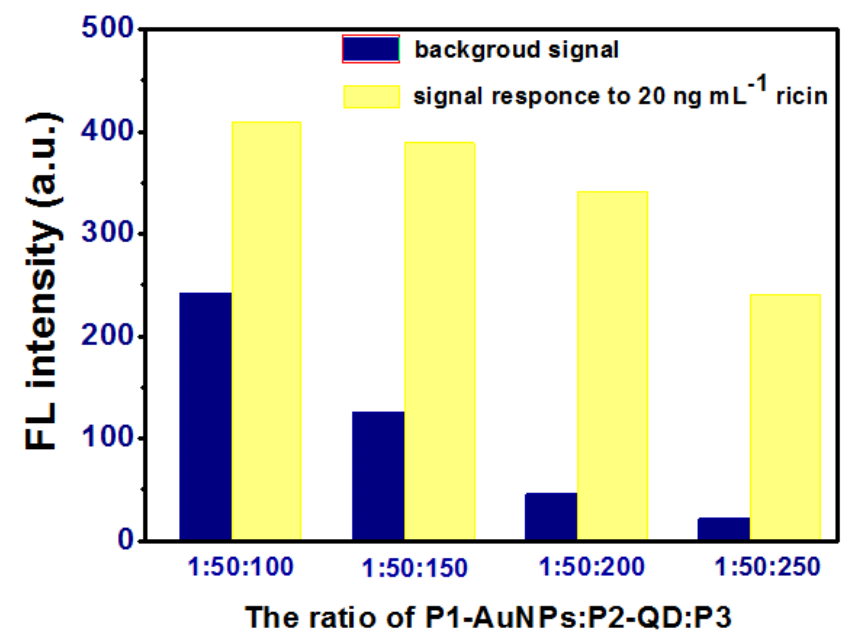

Figure S3. The background signal and the signal response of the AuNP/QDs nanoprobe under different ratios. 


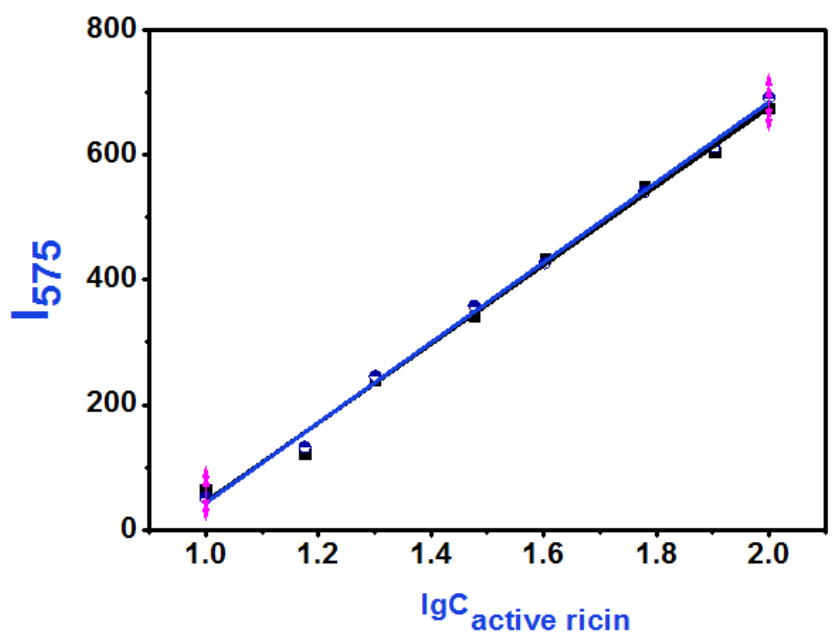

Figure S4. Comparison of the response of AuNP/QDs to active ricin dispersed in ammonium acetate buffer ( $5 \mathrm{mmol} \mathrm{L}^{-1}, \mathrm{pH} 4.0$, blank line), the elution condition (incube 30 ) as well as in diluted elution buffer (blue line) which contained ammonium acetate buffer ( $\left.4.5 \mathrm{mmol} \mathrm{L}^{-1}, \mathrm{pH} 4.0\right), 4.9 \%$ ethanol and TFA (0.1\%). The fluorescence intensity of the AuNP/QDs at $575 \mathrm{~nm}\left(\mathrm{I}_{575}\right)$ was plotted against different concentration of active ricin. 


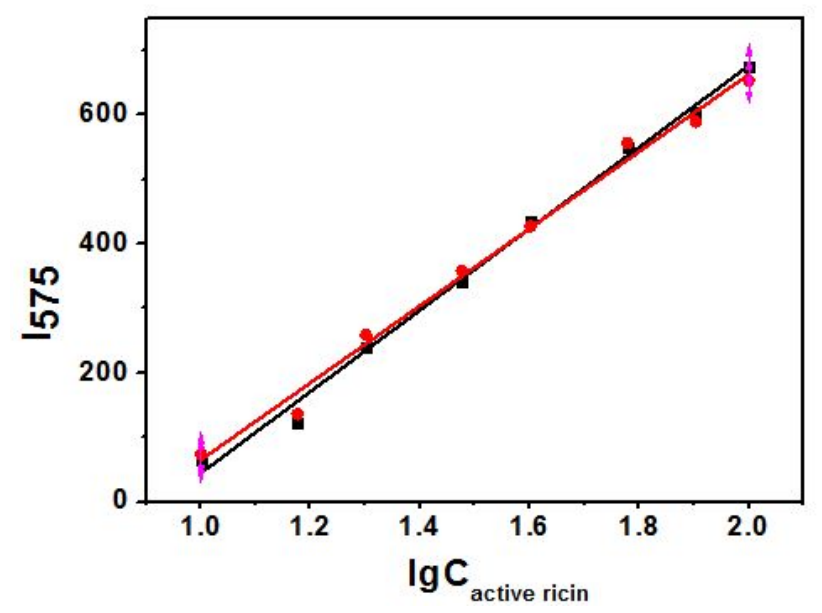

Figure S5. Comparison of the response of AuNP/QDs to active ricin before (blank line) and after (red line) storing 4 months in the PBS under $4^{\circ} \mathrm{C}$. The fluorescence intensity of the AuNP/QDs at $575 \mathrm{~nm}\left(\mathrm{I}_{575}\right)$ was plotted against different concentration of active ricin. 